\title{
Impact of Remittance on Rural Household's Welfare: Evidence from North Wollo Zone, Gubalafto Woreda in Amhara Regional State, Using IV- Estimation Technique
} Tesfaye Gedefaw Wolde*

Department of Economics, School of Business and Economics, Ambo University, Woliso, Ethiopia

*Corresponding author: Tesfaye Gedefaw Wolde, Department of Economics, School of Business and Economics, Ambo University, Woliso, Ethiopia, Tel: +251112362006; E-mail: tesfayewgw@gmail.com

Receiving date: January 27, 2018; Accepted date: Feb 2, 2018; Publishing date: Feb 9, 2018

Copyright: () 2018 Wolde GT. This is an open-access article distributed under the terms of the Creative Commons Attribution License, which permits unrestricted use, distribution, and reproduction in any medium, provided the original author and source are credited.

\begin{abstract}
The ultimate objectives of this paper intended to estimate the impact of remittance income on household's welfare using the household level cross sectional data. The study controls for various household characteristics, assetholding variables, institutional, village level infrastructural variables as well as endogeniety problems using IV estimation. The results indicate that remittances positively and significantly affect household level consumption expenditure. Household characteristics particularly family size, participation on wage employment, distance to the main market and lowland agro ecological zone affect welfare status and access to extension service affects the welfare status positively and significantly. On the other hand, oxen, land size, non-livestock asset, participation on own business, access to credit and access to extension service have positive and significant effect on the household's welfare status.
\end{abstract}

Keywords: Welfare; Impact of remittance; Rural household; Consumption; Human capital

\section{Introductions}

\section{Background of the study}

Remittances remain an especially important and stable source of private inflows to developing countries, as they bring in large amounts of foreign currency that help to sustain the balance of payments. In 2013, remittances were significantly higher than foreign direct investment (FDI) in developing countries (excluding China) and were three times larger than official development assistance (WB, 2014). Remittances generally reduce the level and severity of poverty and lead to higher human capital accumulation; greater health and education expenditures; better access to information and communication technologies; improved access to formal financial sector services; enhanced small business investment; more entrepreneurship; better preparedness for adverse shocks such as droughts, earthquakes, and cyclones; and reduced child labor. Diasporas can be an important source of trade, capital, technology, and knowledge for countries of origin and destination. Officially, recorded remittances to developing countries were an estimated $\$ 404$ billion in 2013, an increase of about $3.3 \%$ over the previous year. Global remittance flows, including highincome countries, reached at $\$ 542$ billion in 2013 (IBID).

Remittance is an extremely important source of foreign exchange for Ethiopia, perhaps larger than the export earning of the country in its foreign exchange generation capacity [1]. It has been an important livelihood strategy among households in most developing countries, and the means to cope up with poverty and economic crisis. Migrant remittance directly reaches to the recipients without and intermediaries, and they can use freely according to their own priorities. International remittance improves the welfare and asset holding of the rural and urban households.
In line to this, the economic impact of migrant remittance has received a greater attention from both researchers and policy makers particularly in the developing countries. International remittance decrease the probability of a family being poor or chronically poor, and it increase the number of children in a family that attend school, suggesting that international remittance increase human capital formation in Ghana [2].

International migration improves the global allocation of labor hence global welfare. However, it is often argued that sending countries lose to the receiving countries when their young and brightest, often educated at public expense, immigrate to developed countries. If remittances improve living standards of sending countries, then such remittances may offset some of the cost to the sending countries. Azam and Gubert [3] argue that remittances have seen as a contingent flow from a joint family decision to send its young ones abroad in exchange for financial flows from the emigrant to smooth the family's consumption pattern.

\section{Rationality}

The impact of migration and remittance on the household's livelihood depends on the net effect of welfare gain or lose from remittance income and production losses due to migration of active labor force. If there is surplus labor in the sending area [4], this labor loss has zero opportunity cost. That is, the migrant sending economy can sacrifice workers to migration without suffering a loss in production. If there were labor shortages in the migrant sending economy (when the area is more productive and fertile), those who migrate would have made a positive contribution to production at the place of origin if they had not migrated. In addition, if those who migrate take capital (both human and financial) with them, the capital stock in migrant sending area declines, reducing the productivity of 
other complementary inputs, including labor [5-7]. Migrant remittance reduces or reverses the negative lost-labor-and-capital effect of migration in two ways. First, its effect through direct contribution to income in the migrant sending areas if the size of remittance exceeds the value of production lost because of emigration. Non- migrants benefit from emigration, even if they do not receive any of the remittance themselves, if the magnitude of migrants' remittance exceeds a critical threshold that is roughly equal to the value of the production they would have produced had they stayed behind. Production in migrant sending areas, however, falls in his model, because of labor and capital lost to emigration [8]. Second, remittance may increase income and stimulate production in migrant sending areas indirectly by enabling economic agents in migrant areas to overcome capital and other constraints as well as risks on production activities [9].

Migrant remittance may positively influence production in migrant sending areas by providing households and firms with scarce capital and by providing national economies with scarce saving and foreign exchange. In general, if the migrant remittances improve living standards of sending countries, then such remittances may offset some of the cost or lose to the sending countries. Household's consumption considered as a measure of welfare achievements by households and it depends on net income of the households, not on the level of aggregate income.

A study on impact of international migrant and remittance on asset holding in rural Philippines using longitudinal data and an instrumental variable approach revealed that remittance positively and significantly affect household's asset holding like housing, consumer durables [10,11]. A study by Anwar and Eberle find out a positive and significant relationship between consumption expenditure of rural farmers and international remittance in Pakistan. Another study by Quartey [12] using instrumental variable methods found that remittances improve household welfare and it is able to minimize the effects of economic shocks to household welfare which is proxied by consumption expenditure, although it is not able to offset the shocks completely except for food crop farmers (the poorest in Ghana).

Andersson [13] examined the impact of remittance on the rural household's welfare particularly on subjective wellbeing in Ethiopia using PSM approach. His study found that the households who received remittance had better welfare status as compared to those who did not have such access. However, the application of PSM in estimating the impact of remittance on household's consumption expenditure was not enough to avoid the immeasurable bias. Another study conducted by Solomon [14] in order to assesses the impact of migrant remittances on expenditure patterns of rural households in Ethiopia. This paper aims to, investigate the extents to which receipts of remittances affect the consumption and investment behaviors of rural households using simple linear regression model. Accordingly, he reveled that there is no strong link between receipt of remittances and productive investment expenditures. The result also indicates that remittances have positive and significant impact on consumption expenditures. However, OLS estimation technique, unable to overcome endogenity problem, which is, comes from either observable or unobservable factors which affect the outcome variables.

Therefore, estimating the impact of remittance on household's welfare required a model that can correct the endogenity problems. Centrally, the paper aims to assess the impact of international remittance on rural household's welfare status (which is proximately, measured by consumption expenditure). As part of the general objective, this research work intends to achieve the following specific objectives as well.

To assess the factors that affects the amount of remittance income at household level

To measure the impact of remittance on the household's welfare

\section{Literature Review}

\section{The patterns of migration and remittance}

Environmental extremes such as drought are decreasing the land's productive capacity leading to a decrease in subsistence agriculture, income, assets, and a rapid decline in the health and nutritional status of the rural population. Ethiopia has a long history of poor infrastructure development, has few risk mitigation, adaptation, and coping strategies, and arguably has poor political will. These constraints have led to a dramatic increase in rural-to-urban migration as a last-resort coping option for poor rural farmers who are responding to the negative environmental extremes.

"Remittances play a critical role in helping households address immediate needs and also invest in the future, so bringing down remittance prices will have a significant impact on poverty," Gaiv Tata, Director of the World Bank's Africa Region and Financial Inclusion and Infrastructure Global Practice said on the report. Interestingly also the report reveals that remittance prices are even higher between African nations. Therefore, the African governments should implement policies to open the remittances market to competition. Increasing competition, creating better-informed consumers, and reducing the costs of bank services should be the primary areas of policy option.

According to the World Bank data, the number of Ethiopians live in abroad reached at 620 thousand in 2010. The total number of Ethiopian Emigrants is equivalent to $0.6 \%$ of the total population of the country. The main destinations of Ethiopians migrants are Sudan, the United States, and Israel; the combined number of Ethiopians in these three countries comprises more than $60 \%$ of Ethiopians abroad (about 380 thousand migrants). Ethiopian workers in Saudi Arabia amount for $4.6 \%$ of Ethiopians abroad. Moreover, Ethiopians in Western Europe amount for $11.2 \%$ of migrants.

In 2010, officially recorded remittances to developing countries reached \$334 billion (World Bank 2010). For many developing countries, remittances constitute a large source of foreign income relative to other financial flows. Remittances are largely personal transactions from migrants to their friends and families; they tend to be well targeted to the needs of their recipients [15].

In 2010, it was estimated to that, the total flow of remittances to the developing world was more than US $\$ 325$ billion outpacing foreign direct investment and aid [16]. By the same year, Kenya, Uganda, and Ethiopia ranked among the top 10 SSA remittance recipients at US $\$ 1.8$, $\$ 0.8$, and $\$ 0.4$ billion [17]. Although displaying year-to-year variability, total remittance inflows have increased in Uganda, Kenya, and Ethiopia between 1999 and 2011.

The total remittance sent to Ethiopia has dramatically increased. According to available data from the WB, 513 and 524 million dollars sent to Ethiopia in 2011 and 2012, respectively. The two percent that remittances contribute to Ethiopia's GDP is, however, far lower than Kenya's three percent, Uganda's six percent and Sudan's one percent. 
Despite the increase of remittances to Ethiopia from 53 USD million in 1990 to 371 USD million in 2011, remittances amount for less than $1 \%$ of the Ethiopian gross domestic product (GDP). In addition, the average value of remittances received per person in is about 4 USD, a low figure compared to other countries in the region [18].

\section{Materials and Methods}

\section{The types and sources of data}

Primarily, household considered as the unit of analysis in this paper. To achieve the above stated objective, the study used mainly primary data collected from household survey in the study area. Structured questionnaire used to collect information on household demographic composition, consumption expenditure (food and non-food expenditure), income, physical capital variables of household including livestock holding; human capital variables that the household will be endowed, access to remittance and other aspects. In general, multipurpose questionnaire used to collect the required primary data. The data collection process held through a personal interview with the households. The study also included secondary data from the Zone (ZoFED), other Zonal office.

\section{Sampling technique}

North Wollo zone is one of the most migrant sending areas in the Amhara regional state. A large numbers of rural people persistently migrated from their rural residence to the nearby urban area within the country and outside the country annually due to different pushing and pulling factors.

The study used multistage sampling procedure to get representative sample households. First, the total numbers of Kebeles were stratifies into three agro ecological zones such as highland, mid-attitude and lowland. Second, considering the number of explanatory variables, only 220 sample households selected as sample. The selected sample households proportionately distributed across the three agroecological zones. Finally, sample household selected using systematic random sampling methods, which is sampling draw of every nth element from a list.

The sample includes only households with international migrants. A migrant is in the survey defined as a person who is living in another country and has been away for at least twelve consecutive months.

\section{Model specification}

The impact of remittance on the rural household consumption expenditure handled through using propensity score matching, instrumental variable methods, or difference-in-difference approaches. However, the last approach required a set of panel data, and the propensity score matching required a sort of data were collected in the pre preprogram intervention to get the true counterfactual. Thus, this article proposed to use the instrumental variable (IV) estimation method. This technique employed through multivariate regression. Multivariate regression used to account for possible differences between participants and the comparison group on measurable characteristics. The regression framework allows the researcher to focus on one parameter of interest, holding the effects of other variables parameterized in the model as constant or unchanging. The outcome of interest is regressed on an indicator of program participation and all measured household and environmental and community characteristics that might affect the outcome. Here, the parameter of interest is the marginal effect on the outcome of participation in the program, netting out the effect of other characteristics. In principle, if all characteristics that affect the outcome variable can be measures and included in the regression, ordinary least square (OLS) estimation produces an unbiased estimate of the impact of a program. Therefore, the impact of remittance income on the household consumption expenditure per adult equivalent household size specified by:

$$
\log W i=\alpha+\beta 1 H i+\beta 2 \mathrm{Ei}+\beta 3 \mathrm{Ai}+\beta 4 \mathrm{Fi}+\beta 5 \mathrm{Ci}+\beta 6 \mathrm{Mi}+\text { ?h }
$$

Where, $\mathrm{Wi}$ is the ratio of consumption expenditure per adult equivalent to the poverty line $\left(\mathrm{C}_{\mathrm{h}} / \mathrm{z}\right)$. The right hand side variables, in the regression including; (Hi) household characteristics such as gender of household head, age of the household head, dependency ratio and family size; (Ei) human capital indicators like household head educational level; ( $\mathrm{Ai}$ ) asset holdings including livestock holding, land size and the value of farm and home assets; ( $\mathrm{Fi}$ ) off-farm income participation, both wage and self-employment; (Ci) community factors like distance to the main market, community services, environmental shocks and kebele dummy; and $(\mathrm{Mi})$ remittance income including both domestic and international remittance. $\beta_{1} \beta_{2}, \ldots . \beta_{6}$ all are the parameters of interest and is household's fixed effect that is unobserved household heterogeneity. The choice of consumption over income as a measure of welfare motivated by the fact that information on consumption is more reliable than information on income in a developing country context. Consumption is also less volatile than income and hence measures average welfare of households better than income. A challenge when estimating the causal impact of migration and remittances on household welfare is the problems of endogenity. Here, access to remittance or remittance income is an endogenous variable. The most common example of endogenity is when a third variable causes two other variables to correlate without there being any causality. When an explanatory variable is endogenous, it is not possible to give an unbiased estimate of the causal effect of this variable. Access to remittance or remittance income affected by a number of variables but not affect the household's welfare directly. The unobserved variables that affect remittance income included in the error term in eqn. (1) and produced:

\section{$\log W i=\alpha+\gamma i H i+\beta i E i+\phi i A i+\rho i F i+\theta i C i+\delta i M i+(? h+\varepsilon X)$}

Where, is a random error term, and is the effect of the unobserved variable. Mi and are correlated and therefore, $\mathrm{Mi}$ is endogenous. Thus, OLS estimation coefficient of remittance income against household welfare in equation (1) leads to biased results. The solution is to specify a reduced form equation for remittance income against to the instrumental variables and other exogenous variable as follow:

\section{$M i=\theta+\pi X i+\phi Z i+\varepsilon I$}

Where, $\mathrm{Z}$ is a vector variable that affects household consumption expenditure only through its effect on the amount of remittance income and $\mathrm{X}$ is a set of exogenous variables that affect both the household consumption expenditure and remittance income. is a normally distributed error term. So that the IV (2SLS) approach is, an appropriate model designed to pick up the impact of remittance on household's welfare. The main important question is to find out a set of regressors in the remittance income equation that affect remittance income/access to remittance but does not directly affect the household's consumption expenditure. Here, we used migrant networks and number of remitters as instruments for the remittance 
Citation: Wolde TG (2018) Impact of Remittance on Rural Household's Welfare: Evidence from North Wollo Zone, Gubalafto Woreda in Amhara Regional State, Using IV-Estimation Technique. J Glob Econ 6: 281. doi:10.4172/2375-4389.1000281

Page 4 of 6

income or the probability of receiving remittance. Migrant networks measured by the number of people in the community (town/ neighborhood) who have migrated in the last 5 years and the number of people who have sent remittances to the household in the last twelve months (remitters) as instruments. The instrumental variable estimation technique becomes applicable if the validity (relevance: $\operatorname{Cov}(Z, X) \neq$ 0;exogenity: $\operatorname{Cov}(z, \mathcal{\varepsilon})=0)$ and over identification, assumption holds true. According to the cumulative theory of migration (Massey et al. 1994), the social networks of migrant friends or relatives play an important role on migration decisions by reducing migration costs and risks, creating path dependence, and facilitating the process of sending remittance safely. We believe that these migration networks do not influence consumption directly but only through the effect of remittance income.

\section{Econometric Results and Discussions on the \\ Determinants of Household Consumption Expenditure Per Adult Equivalent}

The regression result revealed that amount of international remittance has a positive and statistically significant impact on household consumption expenditure. The people who received international remittance had a better welfare as compared to their counterpart. Mean family size adversely and significantly, affect household's consumption expenditure per adult equivalent. It is statistically significant at $1 \%$ significance level, and households with a large family size have lower welfare status than their counterparts.

Considering the asset holding, number of oxen per adult equivalent household size has a significant and positive effect on the welfare of the households and it is statistically significant at $1 \%$ significance level. Similar to the study of households with large number of oxen per adult equivalent had lower poverty status than the one who did not. Holding all other things remains constant, adding one additional ox per adult person increase the household welfare by $39.39 \%$. Land is the most important and main sources of income in rural area of Ethiopia. It is highly linked to the household's welfare status (Table 1).

\begin{tabular}{|c|c|c|c|c|}
\hline Explanatory variables & Coef. & Robust Std. Err. & t-value & P-value \\
\hline International remittance income & $.0000326^{\star *}$ & $1.59 \mathrm{E}-05$ & 2.05 & 0.042 \\
\hline Head male & 0.095031 & 0.066117 & 1.44 & 0.152 \\
\hline Age of household head & 0.009991 & 0.012832 & 0.78 & 0.437 \\
\hline Head age square & -0.00014 & 0.000121 & -1.12 & 0.263 \\
\hline Average family age & 0.004531 & 0.003236 & 1.4 & 0.163 \\
\hline Average family size & $-.0791272^{\star \star *}$ & 0.025626 & -3.09 & 0.002 \\
\hline Dependency ratio & 0.070514 & 0.048874 & 1.44 & 0.151 \\
\hline Number of children under 5 years & -0.04028 & 0.039575 & -1.02 & 0.31 \\
\hline Head education above grade 8 & 0.104474 & 0.134862 & 0.77 & 0.439 \\
\hline Number of oxen per adult equivalent household size & $.3938691^{* * *}$ & 0.121197 & 3.25 & 0.001 \\
\hline Tropical livestock unit per adult equivalent hh size & 0.057741 & 0.065182 & 0.89 & 0.377 \\
\hline Land size per adult equivalent household size & $.3340166^{\star \star *}$ & 0.081964 & 4.08 & 0 \\
\hline Total asset value & $.0000284^{\star \star \star}$ & $5.74 \mathrm{E}-06$ & 4.95 & 0 \\
\hline Employment on own business & $.1622243^{\star *}$ & 0.0763 & 2.13 & 0.035 \\
\hline Employment in hired jobs & $-.1392395^{* *}$ & 0.063648 & -2.19 & 0.03 \\
\hline Access to irrigation & 0.068937 & 0.070509 & 0.98 & 0.329 \\
\hline Access to credit & $.1544489^{* *}$ & 0.062843 & 2.46 & 0.015 \\
\hline Access to extension services & 0.106193 & 0.142743 & 0.74 & 0.458 \\
\hline Application of modern inputs & -0.11428 & 0.092069 & -1.24 & 0.216 \\
\hline Village level infrastructural facility index & 0.10404 & 0.127356 & 0.82 & 0.415 \\
\hline Distance to main market & $-.0005892^{\star *}$ & 0.000247 & -2.38 & 0.018 \\
\hline Drought shocks in the last 5 years & -0.0898 & 0.071891 & -1.25 & 0.213 \\
\hline
\end{tabular}




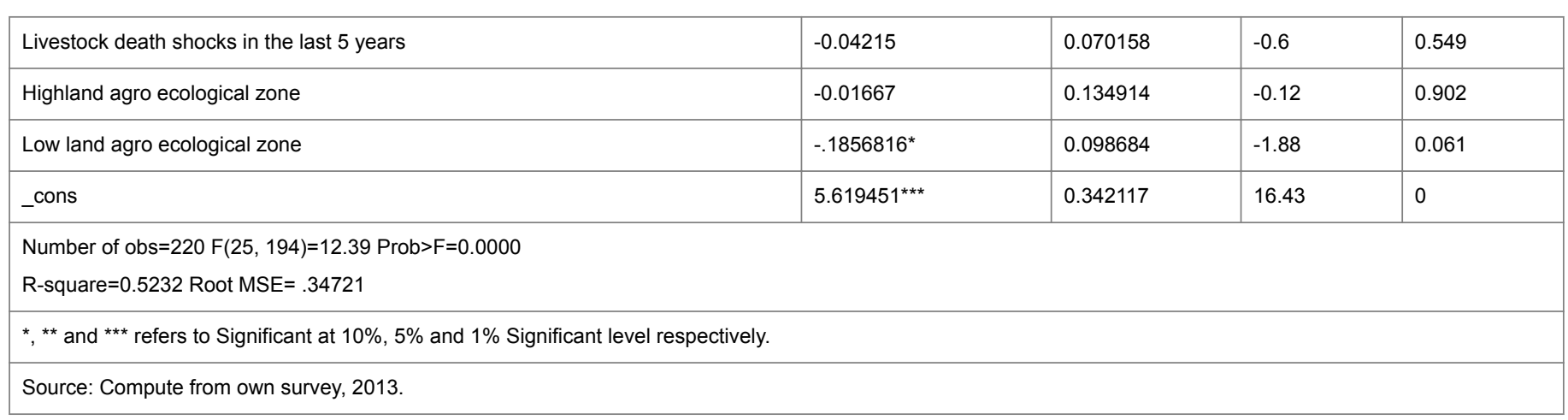

Table 1: Impact of remittance on household consumption expenditure-IV regression.

Land size has positive and statistically significant effect on the household's welfare. The households with large farm size have higher welfare than those who have smaller farm size. As land size per adult equivalent household unit increase by one timad/0.25 hectares, household welfare increase by $33.40 \%$ with ceteris paribus. Nonlivestock asset holding (both farm and household asset) is another important asset in the Gubalafto wereda with having statistically significant and positive effect on household welfare. As a household's possession of current assets increases, its welfare level too increases.

Employment on own business activity (petty trade and others) has a positive impact on household's welfare, and it is statistically significant at $5 \%$ significance level. However, household participation in wage employment has a significant and negative effect on the household's welfare. It means that households engaged in wage employment have lower level of welfare than households not engaged in non-farm or households engaged in own business supporting the popular view that in many developing countries households are forced rather than attracted to enter into non-farm wage employment because of lack of other options. The access to credit enables the households to minimize their financial constraints and helps to purchase oxen, fertilizer, improved seeds and other inputs. The coefficient of access to credit is statistically significant at $5 \%$ significance level. Holding other things remain constant, household's welfare status increases by $15.44 \%$ if the household gets credit access.

Access to main market has significant and negative effect on the household's welfare status. Results indicate that households closer to the main market have higher consumption expenditure per adult equivalent than households who live in remote areas far from the market. The coefficient of the agro ecological dummy has significant and negative impact on welfare, and the households living in the Kolla agro ecological zone have a lower welfare status as compared to the households who lives in the middle altitude. The estimated coefficient is statistically significant at $5 \%$ significance level.

\section{Conclusion and Policy Directions}

The regression result revealed that, remittance income has a positive and statistically significant effect on household's consumption expenditure. Thus, it needed more emphasis to increase inflow of international remittance through investment on human capital and having bilateral relationship with foreign countries.

Higher fertility rate accompanied with scarcity of land size significantly reduce household's welfare. Thus, serious attention should be given by the concerned bodies to curb a higher fertility rate in the study area. Concerned bodies should expand the effective extension services to increase awareness among rural households (both men \& women) through family planning in order to reduce fertility with considering the replacement and the mortality rate in the rural households of Gubalafto woreda.

Asset holding such as, livestock holding (particularly oxen), land size and non-livestock assets, access to irrigation and participation on own businesses activities were significantly enhanced the household's welfare. Therefore, this is an insight that rural household asset bulling program should be implemented to enhance households welfare and reduces poverty.

Public services such as access to credit and agricultural extension services significantly and positively affect household's welfare. Therefore, expanding rural credits and agricultural extension services to subsistence farmers should be one of the main areas of intervention and policy options.

Finally, households far from the main market have a lower level of welfare status. This calls the policy measures to address inadequate market access through investments in marketing infrastructures, such as market area, road access, transportation facilities and agricultural price information systems.

\section{References}

1. IFAD (2011) Rural poverty report 2011: New realities, New challenges: New opportunities for Tomorrow's Generation.

2. Gyimah K, Asiedu E (2009) Remittances and Poverty in Ghana. University of Kansas.

3. Azam JP, Gubert F (2006) Migrants Remittances and the Household in Africa: A Review of Evidence. Journal of African Economies 15: 426-462.

4. Lewis WA (1954) Economic Development with Unlimited Supplies of Labor. The Manchester School 22: 139-191.

5. Johnson HG (1967) Some economic aspects of the brain drain. African Studies Review 9: 7-14.

6. Berry RA, Soligo R (1969) Some welfare aspects of international migration. Journal of Political Economy 77: 778-794.

7. Rivera BF (1982) International migration, non-traded goods and economic welfare in the source country. Journal of Development Economics 11: 81-90.

8. Djajic S (1986) International Migration, Remittance and welfare in a Dependent Economy. Queen's university.

9. Stark O, Bloom DE (1985) The new economics of labor migration. American Economic Review 75: 845-867. 
Citation: Wolde TG (2018) Impact of Remittance on Rural Household's Welfare: Evidence from North Wollo Zone, Gubalafto Woreda in Amhara Regional State, Using IV-Estimation Technique. J Glob Econ 6: 281. doi:10.4172/2375-4389.1000281

Page 6 of 6

10. Quisumbing A, McNiven S (2010) Moving forward, looking back: The impact of migrants' remittances on assets, consumption, and credit constraints in sending communities in the rural Philippines. Journal of Development Studies.

11. Jean PC (2008) Return Migrants to the Maghreb Countries: Reintegration and Development Challenges. European University Institute.

12. Quartey P (2006) The Impact of Migrant Remittances on Household Welfare in Ghana. African Economic Research Consortium (AERC).

13. Andersson L (2012) Migration, Remittances and Household Welfare in Ethiopia department of economics. University of Gothenburg.

14. Solomon M (2013) Migrant Remittances and Expenditure Patterns of Rural Households in Ethiopia: Evidence from ERHS, Addis Ababa, Ethiopia.
15. Ratha D, Z Xu (2007) Migration and remittances fact book. Migration and Remittances Team, Development Prospects Group, World Bank.

16. Yang D (2011) Migrant remittances. Journal of Economic Perspectives 25: 129-152.

17. Dilip R (2011) Leveraging migration for Africa: Remittances, Skills, and Investments. The World Bank, Washington DC.

18. World Bank (2012) Migration and Remittances: Recent Developments and Outlook. 